\title{
Latihan Range of Motion Berpengaruh terhadap Mobilitas Fisik pada Lansia di Balai Pelayanan Sosial Tresna Werdha Unit Abiyoso Yogyakarta
}

\author{
Hermina Desiane Hastini Uda ${ }^{1}$, Muflih$^{1}$, Thomas Aquino Erjinyuare Amigo ${ }^{1}$
}

Universitas Respati Yogyakarta

Jl. Laksda Adisucipto Km. 6,3, Depok, Caturtunggal, Sleman, Kabupaten Sleman, Daerah Istimewa Yogyakarta 55281

Email: erjin.respati2009@gmail.com

\begin{abstract}
Abstrak
Peningkatan usia harapan hidup (UHH) menyebabkan pertambahan populasi lansia. Populasi lansia tertinggi di Indonesia berada di Daerah Istimewa Yogyakarta dengan persentase sebesar 13,05\%. Seiring dengan peningkatan $\mathrm{UHH}$, lansia mengalami perubahan normal maupun patologis yang berkaitan dengan proses penuaan dalam berbagai sistem. Perubahan normal terlihat pada sistem muskuloskeletal berupa penurunan otot secara keseluruhan pada usia 80 tahun (30\%-50\%). Perubahan patologis seperti rheumatoid arthritis, osteoarthritis, dan osteoporosis. Perubahan tersebut menyebabkan lansia rentan mengalami hambatan dalam mobilitas fisik yang dapat diatasi dengan memberikan intervensi berupa latihan range of motion (ROM). Tujuan penelitian untuk mengetahui pengaruh latihan ROM terhadap mobilitas fisik pada lansia di Balai Pelayanan Sosial Tresna Werdha Unit Abiyoso Yogyakarta. Penelitian kualitatif dengan pendekatan action research. Penelitian dilakukan di BPSTW Unit Abiyoso Yogyakarta dengan jumlah sampel 5 partisipan. Teknik pengambilan sampel yang digunakan purposive sampling. Hasil penelitian mobilitas fisik lansia terdiri dari lima tema yaitu rentang gerak, kekuatan otot, kenyamanan, postur tubuh dan gerakan. Latihan ROM memberi perubahan pada rentang gerak, kenyamanan dan gerakan tetapi kekuatan otot dan postur tubuh tidak ada perubahan. Perubahan rentang gerak berupa peningkatan derajat rentang gerak yang banyak terlihat pada area leher dan kekakuan sendi yang berkurang. Kenyamanan mengalami perubahan berupa perasaan senang, nyeri yang berkurang, tetapi masalah sesak nafas tidak berkurang. Perubahan gerakan yang berbeda-beda pada setiap lansia yang terlihat pada cara dan kemampuan berjalan yang lebih cepat dari sebelumnya, kemampuan motorik halus meningkatkan kenyamanan, dan pengalaman gemetar yang berkurang. Kesimpulan ada pengaruh sebagian latihan ROM terhadap mobilitas fisik lansia meliputi peningkatan rentang gerak, kenyamanan dan cara berjalan, sedangkan postur tubuh dan kekuatan otot pada lansia tidak mengalami perubahan.
\end{abstract}

Kata Kunci: range of motion, mobilitas fisik, lansia

\section{Range of Motion Exercises Has The Effect against Physical Mobility for The Elderly in Center for Social Services, Tresna Werdha, Unit Abiyoso Yogyakarta}

\begin{abstract}
The increasing of life expectancy has raised the population of the elderly. The highest population number of elderly in Indonesia can be found in Yogyakarta Special Region with 13.05\%. The increasing life expectancy brings normal and pathological changes in the elderly as it relates to aging process in various systems. Normal changes are seen in the musculoskeletal system that is in the complete loss of muscle at the age of 80 (30\%$50 \%$ ). The changes can be found in such cases as rheumatoid arthritis, osteoarthritis, and osteoporosis. Such changes have made the elderly susceptible to hindrances of physical mobility which can be treated by giving range of motion (ROM) Exercises. The purpose of study was to find out the effect of ROM Exercises against physical mobility for the elderly in Center for Social Services, Tresna Werdha, Unit Abiyoso Yogyakarta. This study was a qualitative research with an action research design. A purposive sampling method was used
\end{abstract}


to collect the data from 5 respondents. As the results physical mobility in elderly consists of five themes, namely range of motion, muscle strength, comfort, posture, and movement. ROM exercises provides changes in the ROM, comfort, and movement, but no change in the muscle strength and posture. Changes in the range of motion are found in the increased level of the range of motion which is seen in neck area and in reduced joint stiffness. Changes in comfort are seen in a feeling of happiness and less pain; yet, shortness of breath is not reduced. Changes in movement, which are different for every elderly, can be seen in increased gait speed, increased comfort which is the effect of fine motor skills, and decreased trembling. As conclusion, some ROM exercises show effects on the physical mobility of the elderly. The effects can be traced from increased range of motion, comfort, and gait speed. Yet, the elderly's posture and muscle strength do not experience any changes.

Keywords: range of motion, physical mobility, elderly

\section{Info Artikel:}

Artikel dikirim pada 21 September 2016

Artikel diterima pada 17 November 2016

DOI : http://dx.doi.org/10.21927/jnki.2016.4(3).169-177

\section{PENDAHULUAN}

Lanjut usia merupakan fase akhir kehidupan ditandai dengan penuaan yang menjadi proses normal kehidupan. Lansia memiliki usia harapan hidup yang cukup tinggi. Hal ini dapat dilihat dari usia harapan hidup (UHH) dunia tahun 2013 untuk populasi berusia 60 tahun rata-rata dapat bertahan hidup selama 20 tahun (1). Indonesia mengalami peningkatan $\mathrm{UHH}$ secara nyata. Hasil Sensus Penduduk tahun 2010 menunjukkan bahwa penduduk Indonesia memiliki UHH mencapai 70,7 tahun (2). Daerah Istimewa Yogyakarta merupakan salah satu kota di Indonesia yang memiliki UHH paling tinggi padatahun 2011 yaitu sebesar 73,27 tahun (3).

Peningkatan UHH menyebabkan populasi lansia meningkat. Populasi di Indonesia tahun 2014 mencapai 20,24 juta jiwa atau setara dengan $8,03 \%$. Salah satu kota yang mempunyai populasi lansia tertinggi di Indonesia adalah Daerah Istimewa Yogyakarta dengan persentase jumlah lansia sebesar $13,05 \%$ (2). Seiring dengan peningkatan $\mathrm{UHH}$, lansia mengalami perubahan normal maupun patologis yang berkaitan dengan proses penuaan dalam berbagai sistem. Proses perubahan tersebut menyebabkan penurunan fungsi sistem muskuloskeletal yang menyebabkan lansia rentan mengalami hambatan dalam mobilitas fisik (1).

Perubahan normal akibat penuaan ini paling jelas terlihat pada sistem muskuloskeletal berupa penurunan otot secara keseluruhan pada usia 80 tahun mencapai $30 \%$ sampai $50 \%$ (4). Perubahan patologis pada sistem muskuloskeletal seperti rheumatoid arthritis, osteoarthritis, dan osteoporosis yang sering terjadi pada lansia menyebabkan hambatan mobilitas fisik. Kejadian rheumatoid athritis 20-300/100.000 orang per tahun. Usia 70 tahun sebesar $40 \%$ menderita osteoarthritis dan $80 \%$ dari pasien dengan osteoarthritis memiliki beberapa tingkat keterbatasan gerakan, serta $25 \%$ tidak dapat melakukan kegiatan sehari-hari mereka.

Hambatan mobilitas yang diakibatkan oleh perubahan patologis pada sistem muskuloskeletal memberikan dampak pada fisik maupun psikososial pada lansia. Dampak fisik dari gangguan mobilitas paling jelas terlihat pada sistem muskuloskeletal berupa penurunan kekuatan dan ketangkasan otot, kontraktur yang membatasi mobilitas sendi, kekakuan dan nyeri pada sendi. Hambatan mobilitas fisik juga memberikan dampak buruk pada sistem kardiovaskuler, pernapasan, metabolik, perkemihan, pencernaan dan integumen berupa penurunan kemampuan atau fungsi dari jantung, pembuluh darah, paru-paru, terganggunya metabolisme tubuh, gangguan fungsi ginjal, kerusakan kulit, serta gangguan pada proses pencernaan. Dampak psikososial dari hambatan mobilitas fisik yaitu respon emosional yang bervariasi (frustasi dan penurunan harga diri, apatis, menarik diri, regresi, dan marah serta agresif), kurangnya stimulasi intelektual menurunkan kemampuan menyelesaikan masalah dan mengambil keputusan, gangguan pada perkembangan sosial yaitu terjadi hambatan dalam interaksi dengan orang lain maupun lingkungan $(5,6)$.

Masalah mobilitas yang terjadi pada lansia dapat diatasi dengan memberikan intervensi berupa latihan range of motion, kontraksi otot isometrik dan 
isotonik, kekuatan/ketahanan, aerobik, sikap, dan mengatur posisi tubuh (5-7). Latihan range of motion adalah latihan pergerakan maksimal yang dilakukan oleh sendi (5). Latihan range of motion menjadi salah satu bentuk latihan yang berfungsi dalam pemeliharaan fleksibilitas sendi dan kekuatan otot pada lansia (7).

Terjadi peningkatan fleksibilitas sendi setelah diajarkan latihan berbentuk range of motion selama 6 minggu dengan $5 x$ latihan dalam seminggu. Peningkatan kecenderungan tulang belakang pada kelompok terlatih ROM sebesar $16,4 \%$, rentang gerak sacral/hip 29,2\%, dan rentang gerak dada $22,5 \%$ dibandingkan dengan kelompok kontrol setelah periode latihan (8). Berdasarkan penelitian tersebut, latihan range of motion dapat menjadi salah satu intervensi untuk mengatasi masalah pada sendi dan otot, sehingga penelitian tersebut dapat menjadi acuan dalam memberikan intervensi bagi lansia yang mengalami hambatan dalam mobilitas fisik. Intervensi tersebut dapat diberikan karena kondisi hambatan mobilitas fisik juga ditandai dengan penurunan kekuatan otot dan rentang gerak yang merupakan masalah pada otot dan sendi.

Berdasarkan hasil studi pendahuluan yang dilakukan di Balai Pelayanan Sosial Tresna Wredha (BPSTW) Unit Abiyoso Yogyakarta pada tanggal 14 Desember 2015 didapatkan jumlah lansia sebesar 126 orang yang bersumber dari petugas dan catatan pada setiap ruangan di panti sosial tersebut. Hasil wawancara yang dilakukan pada 15 orang lansia didapatkan riwayat kesehatan lansia yang berhubungan dengan masalah mobilitas fisik yaitu 3 orang lansia mengatakan memiliki riwayat osteoporosis, 5 orang lansia memiliki riwayat cedera, dan 7 orang lansia mengatakan mengalami nyeri serta kekakuan pada sendi sehingga kesulitan dalam melakukan mobilitas fisik. Keluhan yang dirasakan lansia berupa kesulitan dalam menggerakkan anggota tubuh, berjalan lebih lambat, kesulitan dalam melakukan aktivitas berat, kesulitan bernafas jika berjalan dan sebagian besar lansia menggunakan alat bantu jalan.

Kegiatan yang terdapat di BPSTW yaitu senam, mendengarkan musik gamelan, menari, memuat ketrampilan dan bimbingan rohani. Kegiatan di BPSTW Unit Abiyoso Yogyakarta memberikan manfaat bagi lansia berupa kebugaran fisik dan menurunkan kecemasan serta membantu lansia dalam berinteraksi dengan lingkungan. Walaupun sudah mengikuti kegiatan yang ada di BPSTW Unit Abiyoso Yogyakarta, lansia masih merasakan beberapa gejala yang menjadi karakteristik hambatan dalam melakukan mobilitas fisik dapat dilihat dari hasil studi pendahuluan. Berdasarkan informasi dari petugas BPSTW Unit Abiyoso Yogyakarta, penelitian sebelumnya mengenai latihan range of motion belum tersedia. Berdasarkan data yang didapatkan dari hasil studi pendahuluan, dilakukan penelitian tentang latihan range of motion terhadap mobilitas fisik lansia di BPSTW UnitAbiyoso Yogyakarta.

\section{BAHAN DAN METODE}

Penelitian ini menggunakan jenis penelitian kualitatif dengan pendekatan action research yang bertujuan untuk melakukan perubahan pada suatu masalah dengan memberikan sebuah intervensi atau tindakan yang dipantau oleh peneliti sehingga hasil dari perubahan tersebut dapat dimanfaatkan (9). Populasi dalam penelitian yang akan dilakukan adalah seluruh lansia di Balai Pelayanan Sosial Tresna Werdha Unit Abiyoso Yogyakarta dengan jumlah populasi yaitu 126 orang. Teknik pengambilan sampel yang digunakan dalam penelitian adalah purposive sampling.

Partisipan yang diteliti adalah lansia yang memenuhi kriteria berikut ini: bersedia untuk dijadikan partisipan penelitian, berusia di atas 60 tahun, mengalami hambatan mobilitas fisik, memiliki riwayat penyakit osteoporosis, rheumatoid arthritis, dan osteoarthritis. Kriteria eksklusi dari penelitian yang dilakukan yaitu lansia yang memiliki: gangguan mental, gangguan pendengaran dan penglihatan, dislokasi dan fraktur, lansia yang memiliki gangguan pada jantung, dan paru. Sampel pada penelitian 5 partisipan yang dipilih berdasarkan kriteria yang ditentukan. Validasi data menggunakan teknik methodological triangulation.

\section{HASIL DAN BAHASAN}

Setelah melakukan analisis data pada hasil penelitian berupa transkip wawancara dan hasil observasi dari lima partisipan, didapatkan 5 tema tentang mobilitas fisik lansia yaitu rentang gerak kekuatan otot, kenyamanan, postur tubuh dan gerakan. 


\section{Rentang Gerak}

Hasil penelitian terkait rentang gerak dari partisipan didapatkan terjadi peningkatan derajat rentang derajat gerak sendi dan perubahan kondisi sendi. Lebih jelasnya dapat dilihat dari Tabel 1 dan Tabel 2.

Hasil observasi rentang gerak pada Tabel 1 menunjukkan bahwa terjadi peningkatan derajat pergerakan sendi setelah diberikan latihan ROM. Peningkatan rentang gerak antara pertisipan berbeda-beda dan yang paling menonjol adalah pada bagian leher, bahu, siku, tangan dan jari serta lutut. Derajat peningkatan tertinggi terlihat pada bahu kanan dengan tipe gerakan fleksi sebesar $20^{\circ}$ dan tipe gerakan yang banyak terlihat perubahannya adalah tipe gerakan fleksi. Hal tersebut sesuai dengan hasil observasi yang menunjukkan bahwa gerakan fleksi paling sering muncul pada setiap bagian tubuh partisipan yang mengalami peningkatan.

Perubahan lain dari rentang gerak yang ditemukan pada penelitian yang dilakukan berupa perubahan pada kondisi sendi meliputi kekakuan sendi, pembengkakan, dan pergerakan yang tidak sama. Setelah 6 kali melakukan latihan hasil wawancara pada salah satu partisipan menunjukkan bahwa:

"ha-ah kalau pagi bangun tidur tuh cuman gini mba tapi nanti kalau udah aku udah mandi udah kena aer itu bisa buat gini ho-oh jadi harusnya ya harus gerak-gerak terus harus digerak-gerakan kalau ngga kaku. ha-ah bangun tidur, turun dari tempat tidur itu kakinya ta' gerak-gerakan, kaki, tangan kepala... nanti kalau udah agak lemes gitu baru bangun sama duduk ta'gini-giniin lagi kakiku (menggerakkan kaki seperti gerakan fleksi dan ekstensi) ya sebisanya, seingetnya hahaha pokoknya yang terasa sakit tuh trus ta' terusin gitu mba tapi lama kelamaan kalau merasa sakit ta' giniginikan (menggerakkan kaki) trus hilang sendiri sakitnya. Kan kaku mba kalau udah lemeskan ngga ini ngga sakit" (P1)

Hasil wawancara di atas menunjukkan setelah dilakukan latihan ROM sebanyak 6 kali untuk partisipan 1 dan 2 sedangkan 4 kali untuk partisipan 3, 4, 5 sebanyak 4 kali latihan mengalami perubahan pada kondisi sendi berupa bekurangnya kekakuan
Tabel 1. Derajat Perubahan Rentang Gerak

\begin{tabular}{|c|c|c|c|c|c|}
\hline $\mathbf{P}$ & BT & TG & Pre & Post & DP \\
\hline \multirow[t]{7}{*}{1} & $\mathrm{~L}$ & Fleksi & $40^{\circ}$ & $45^{\circ}$ & $5^{\circ}$ \\
\hline & & ekstensi & $30^{\circ}$ & $35^{\circ}$ & \\
\hline & & Rotasi & $68^{\circ}$ & $70^{\circ}$ & \\
\hline & B & Rotasi eksternal & $50^{\circ}$ & $60^{\circ}$ & $10^{\circ}$ \\
\hline & $S$ & Fleksi & $\begin{array}{c}\text { Kanan } \\
70^{\circ} \\
\text { Kiri } \\
68^{\circ}\end{array}$ & $\begin{array}{c}\text { Kanan } \\
72^{\circ} \\
\text { Kiri } \\
70^{\circ}\end{array}$ & $2^{\circ}$ \\
\hline & PT & Fleksi & $\begin{array}{c}\text { Kanan } \\
70^{\circ} \\
\text { Kiri } \\
60^{\circ}\end{array}$ & $\begin{array}{c}\text { Kanan } \\
80^{\circ} \\
\text { Kiri } \\
70^{\circ}\end{array}$ & $10^{\circ}$ \\
\hline & Lt & Fleksi & $120^{\circ}$ & $125^{\circ}$ & $5^{\circ}$ \\
\hline \multirow[t]{3}{*}{2} & $\mathrm{~L}$ & Rotasi & $60^{\circ}$ & $63^{\circ}$ & $3^{\circ}$ \\
\hline & B & Fleksi & $\begin{array}{c}\text { Kanan } \\
80^{\circ} \\
\text { Kiri } \\
70^{\circ}\end{array}$ & $\begin{array}{c}\text { Kanan } \\
90^{\circ} \\
\text { Kiri } \\
80^{\circ}\end{array}$ & $10^{\circ}$ \\
\hline & TJ & Fleksi & $100^{\circ}$ & $97^{\circ}$ & $3^{\circ}$ \\
\hline \multirow[t]{5}{*}{3} & $\mathrm{~L}$ & Rotasi & $45^{\circ}$ & $50^{\circ}$ & $5^{\circ}$ \\
\hline & B & Ekstensi kanan & $80^{\circ}$ & $100^{\circ}$ & $20^{\circ}$ \\
\hline & S & Fleksi & $\begin{array}{c}\text { Kanan } \\
80^{\circ} \\
\text { Kiri } \\
60^{\circ}\end{array}$ & $\begin{array}{c}\text { Kanan } \\
90^{\circ} \\
\text { Kiri } \\
70^{\circ}\end{array}$ & $10^{\circ}$ \\
\hline & TJ & Fleksi & $\begin{array}{c}\text { Kanan } \\
75^{\circ} \\
\text { Kiri } \\
85^{\circ}\end{array}$ & $\begin{array}{c}\text { Kanan } \\
77^{\circ} \\
\text { Kiri } \\
87^{\circ}\end{array}$ & $2^{\circ}$ \\
\hline & L & Fleksi & $\begin{array}{c}\text { Kanan } \\
70^{\circ} \\
\text { Kiri } \\
80^{\circ}\end{array}$ & $\begin{array}{c}\text { Kanan } \\
72^{\circ} \\
\text { Kiri } \\
82^{\circ}\end{array}$ & $2^{\circ}$ \\
\hline \multirow[t]{7}{*}{4} & $L$ & Fleksi & $49^{\circ}$ & $51^{\circ}$ & $2^{\circ}$ \\
\hline & & Ekstensi & $39^{\circ}$ & $41^{\circ}$ & \\
\hline & & Hiperekstensi & $40^{\circ}$ & $42^{\circ}$ & \\
\hline & & Rotasi & $58^{\circ}$ & $60^{\circ}$ & \\
\hline & Siku & Fleksi & $140^{\circ}$ & $142^{\circ}$ & $2^{\circ}$ \\
\hline & & Supinasi & $\begin{array}{c}\text { Kanan } \\
60^{\circ} \\
\text { Kiri } \\
55^{\circ}\end{array}$ & $\begin{array}{c}\text { Kanan } \\
62^{\circ} \\
\text { Kiri } \\
57^{\circ}\end{array}$ & \\
\hline & & Pronasi & $58^{\circ}$ & $60^{\circ}$ & \\
\hline \multirow[t]{4}{*}{5} & L & Ekstensi & $40^{\circ}$ & $42^{\circ}$ & $2^{\circ}$ \\
\hline & & Hiperekstensi & $42^{\circ}$ & $44^{\circ}$ & \\
\hline & & Rotasi & $65^{\circ}$ & $67^{\circ}$ & \\
\hline & TJ & Fleksi & $\begin{array}{c}\text { Kanan } \\
99^{\circ} \\
\text { Kiri } \\
95^{\circ}\end{array}$ & $\begin{array}{c}\text { Kanan } \\
102^{\circ} \\
\text { Kiri } \\
98^{\circ}\end{array}$ & $3^{\circ}$ \\
\hline
\end{tabular}

Keterangan: B: Bahu, BT: Bagian tubuh, L: leher, Lt: Lutut, P: Partisipan, TJ: Tangan dan jari, TG: Tipe gerakan, DP: Derajat perubahan 
pada sendi. Kekakuan sendi tersebut berkurang hanya pada saat partisipan menggerakkan tangannya dan akan muncul lagi pada saat partisipan tidak menggerakkan tubuhnya. Hasil wawancara juga didukung oleh hasil observasi yang menunjukkan perubahan pada kondisi sendi sebelum dan setelah dilakukan latihan ROM. Tabel 2 merupakan hasil observasi pada masing-masing partisipan:

Tabel 2. Perubahan Kondisi Sendi

\begin{tabular}{lllll}
\hline P & & & Setelah Latihan ROM \\
\hline & F & $\begin{array}{l}\text { Kekakuan } \\
\text { sendi }\end{array}$ & Pembengkakan & $\begin{array}{l}\text { Pergerakan } \\
\text { tidak sama }\end{array}$ \\
\hline $\mathbf{1}$ & $6 \times$ & Berkurang & Tidak ada & Sama \\
$\mathbf{2}$ & $6 \times$ & Berkurang & Tidak ada & Sama \\
$\mathbf{3}$ & $4 \times$ & Berkurang & Tidak ada & Sama \\
$\mathbf{4}$ & $4 \times$ & Sama & Tidak ada & Sama \\
$\mathbf{5}$ & $4 \times$ & Sama & Masih ada & Sama \\
\hline
\end{tabular}

Tabel 2 menunjukkan bahwa pada 5 partisipan yang diteliti mengalami kekakuan sendi dan pergerakan yang tidak sama serta terjadi pembengkakan pada salah satu partisipan. Masalah pada kondisi sendi tersebut mengalami perubahan setelah diberikan latihan ROM dengan frekuensi latihan yang berbedabeda. Perubahan tersebut terlihat pada partisipan 1 , 2 dan 3 berupa kekakuan sendi yang berkurang dan tidak terjadi perubahan pada kondisi sendi partisipan 5. Hasil observasi pada Tabel 2 didukung oleh fieldnote atau catatan lapangan berikut yang menunjuk bahwa partisipan 3 dan 5 merupakan partisipan yang cenderung lebih aktif dalam melakukan kegiatan, berbeda dengan partisipan 4 yang tidak aktif dalam melakukan kegiatan. Deformitas juga terdapat pada pergelangan tangan kiri partisipan 3 .

Rentang gerak merupakan pergerakan maksimal yang dapat dilakukan oleh sendi. Rentang gerak seseorang dapat diukur dengan melihat kondisi sendi meliputi kekakuan sendi, pembengkakan, nyeri, keterbatasan gerak dan pergerakan yang tidak sama (6). Rentang pergerakan sendi berbeda-beda antar individu dan ditentukan oleh susunan genetik, pola perkembangan, penyakit, jumlah aktivitas fisik normal yang dilakukan (5).

Berdasarkan data hasil observasi, wawancara, catatan lapangan penelitian dan teori yang mendukung menunjukkan bahwa latihan ROM berpengaruh terhadap mobilitas fisik lansia yang ditandai dengan perubahan pada rentang gerak. Perubahan rentang gerak pada tiap lansia berbeda-beda serta dipengaruhi oleh penuaan, perubahan pada kondisi sendi, dan penurunan kemampuan melakukan aktivitas yang terlihat pada derajat pergerakan sendi dan kondisi sendi. Hal tersebut dapat dibuktikan pada derajat rentang gerak lansia pada beberapa bagian tubuh tidak mengalami perubahan setelah diberikan latihan ROM dan tidak terdapat perubahan pada kondisi sendi dari partisipan yang tidak aktif melakukan kegiatan, terdapat deformitas dan pembangkakan pada sendi.

\section{Kekuatan Otot}

Hasil analisis data menunjukkan bahwa kekuatan otot lansia terdiri dari satu sub tema atau kategori yaitu derajat kekuatan otot. Setelah empat hari melakukan latihan ROM pada partisipan 3, 4, 5 dan enam hari melakukan latihan ROM pada partisipan 1 dan 2 dengan frekuensi latihan 1 kali dalam sehari kekuatan otot lansia tidak mengalami peningkatan. Hal tersebut sesui dengan hasil observasi pada pertemuan pertemuan pertama dan terakhir untuk masing-masing partisipan sama. Tabel 3 berikut merupakan hasil observasi derajat kekuatan otot:

Tabel 3. Derajat Perubahan Kekuatan Otot

\begin{tabular}{lll}
\hline Partisipan & $\begin{array}{r}\text { Kekuatan Otot Sebelum Latihan ROM dan } \\
\text { Sesudah Latihan ROM }\end{array}$ \\
\hline P1, P3, P4, & Ekstermitas atas: 4 & Ekstremitas atas: 4 \\
P5 & Ekstremitas bawah: & Ekstremitas bawah: 4 \\
\hline P2 & Ekstremitas atas: 3 & Ekstremitas atas: 3 \\
& Ekstremitas bawah: 3 & Ekstremitas bawah: 3 \\
\hline
\end{tabular}

Pada penuaan terjadi perubahan berupa menurunnya ukuran dan jumlah dari serat otot (atropi) sehingga menyebabkan penurunan stabilitas dari kekuatan otot (4). Otot harus terus dilatih atau penggunaan otot secara terus menerus dapat menjaga fungsi dan kekuatannya. Kondisi imobilitas dan tirah baring merupakan penyebab terjadinya pengecilan ukuran otot sebagai akibat kehilangan masa dan kekuatan otot (10). Latihan kontraksi otot isometrik dan isotonik, kekuatan/ketahanan, aerobik, sikap, dan mengatur posisi tubuh dapat menjadi intervensi tambahan yang mendukung latihan ROM pada lansia (5-7).

Berdasarkan hasil penelitian di BPSTW Unit Abiyoso Yogyakarta dan teori dapat disimpulkan bahwa latihan ROM tidak memberikan perubahan pada kekuatan otot disebabkan pada penuaan terjadi atrofi otot sehingga latihan ROM tidak dapat menjadi intervensi tunggal untuk menangani penurunan kekuatan otot pada lansia. Latihan ROM harus juga 
disertai dengan intervensi lainnya dengan pengaturan waktu latihan yang teratur dan penambahan aktivitas sehari-hari juga dapat membantu meningkatkan kekuatan otot lansia.

Intervensi ROM dapat meningkatkan rentang gerak sendi di bahu dan pergelangan tetapi tidak memberikan efek pada sendi siku serta tidak terdapat perbedaan yang signifikan dari kekuatan atau kelenturan otot antara kelompok (11).

\section{Kenyamanan}

Hasil analisis data menununjukkan bahwa kenyamanan terdiri dari 4 sub tema atau kategori yaitu: perasaan, kecemasan, nyeri dan sesak nafas. Berdasarkan hasil wawancara menunjukkan bahwa partisipan memiliki tingkat kenyamanan yang sama berkaitan dengan kemampuan lansia dalam melakukan mobilitas fisik. Setelah empat hari melakukan latihan ROM dilakukan evaluasi mengenai perasaan partisipan. Berikut ini penyataan partisipan 3, 4, dan 5:

\section{"ya, nyaman, mungkin urat pada kedudut-dudut gitu ya, ketarik-ketarik hahahaha saya ngomong agak campur aduk. Ya lebih enakan.(tersenyum selama latihan)" (P3) \\ "ya seneng bisa gerak hanya ini takut (sambil memegang dada) sakit ini ikut sesak hahaha" (P4) \\ "ya, senang, nyaman, soalnya saya biasa olah raga itu. Oh ngga ada rasa takut malah enak, bisa melancarkan darah" (P5)}

Hasil wawancara menunjukkan bahwa latihan ROM dapat menimbulkan perasaan yang menyenangkan bagi lansia dan mengalihkan pikiran lansia dari hal-hal yang dapat mengganggu kemampuannya melakukan mobilitas fisik. Setelah pertemuan keenam, partisipan 1 dan 2 mengungkapkan bahwa nyeri berkurang. Berikut pernyataan partisipan:

"ya, nyeri-nyerinya udah banyak berkurang.

Pertama sering dilatih senam, kedua ya ada obatnya kan" (P1)

Hasil penelitian menunjukkan bahwa latihan ROM memengaruhi tingkat kenyamanan lansia sesuai dengan pernyataan partisipan yang memperlihatkan perubahan pada respon perasaan dan nyeri. Hasil wawancara menunjukkan bahwa latihan ROM dapat menjadi salah satu latihan untuk mengalihkan perasaan lansia dari keadaan yang jenuh berubah menjadi menyenangkan. Berdasarkan hasil penelitian pada 5 partisipan menunjukkan bahwa latihan ROM dapat menjadi salah satu bentuk intervensi untuk mengalihkan pengalaman nyeri pada lansia. Latihan ROM juga didukung oleh pengobatan yang teratur untuk mengurangi nyeri yang dirasakan lansia. Hasil lain dari kenyamanan yaitu tidak ada perubahan pada keluhan sesak nafas partisipan. Hal tersebut dapat dipengaruhi oleh riwayat kesehatan dari partisipan yaitu asma. Hasil wawancara dan catatan lapangan juga menunjukkan bahwa tingkat kenyamanan juga dipengaruhi oleh lingkungan, riwayat jatuh dan riwayat fraktur yang menyebabkan gangguan rasa nyaman saat melakukan mobilitas fisik.

Kenyamanan merupakan salah satu kebutuhan dasar yang juga dapat meningkatkan mobilitas fisik seseorang. Kenyamanan dapat diidentifikasi pada empat hal yaitu: fisik (berhubungan dengan sensasi tubuh), sosial (hubungan interpersonal, keluarga dan sosial), psikospiritual (harga diri, seksualitas dan makna hidup), dan lingkungan (pengalaman eksternal) (6). Salah satu penatalaksanaan nonfarmakologi pada nyeri yaitu aktivitas distraksi. Distraksi dapat menjauhkan perhatian dan mengurangi persepsi terhadap rasa nyeri serta dalam beberapa keadaan distraksi dapat membuat klien benar-benar tidak menyadari rasa nyeri dengan memfokuskan perhatian dan konsentrasi pada stimulasi yang lain $(5,6)$.

Berdasarkan data di atas, dapat disimpulkan bahwa latihan ROM dapat menjadi salah satu bentuk distraksi atau pengalihan dari kondisi ketidaknyamanan lansia. Latihan ROM juga harus disertai dengan pemberian obat-obatan untuk beberapa lansia dengan masalah kesehatan tertentu. Lingkungan dan riwayat penyakit dahulu juga merupakan beberapa faktor yang memengaruhi keefektifan dari pemberian latihan ROM.

\section{Postur Tubuh}

Hasil penelitian yang dilakukan pada 5 partisipan menunjukkan kelainan pada postur tubuh yang diobservasi selama partisipan berdiri dan duduk. Hasil observasi pada pertemuan pertama ditunjukkan Tabel 4. 
Tabel 4. Perubahan Postur Tubuh

\begin{tabular}{|c|c|}
\hline Partisipan & $\begin{array}{l}\text { Postur Tubuh Sebelum dan } \\
\text { Sesudah Latihan ROM }\end{array}$ \\
\hline P1, P3 & $\begin{array}{l}\text { Berdiri: punggung membungkuk, kaki } \\
\text { terbuka lebar dan kepala } \\
\text { condong kedepan } \\
\text { Duduk: punggung membungkuk, kepala } \\
\text { condong ke depan }\end{array}$ \\
\hline P2 & 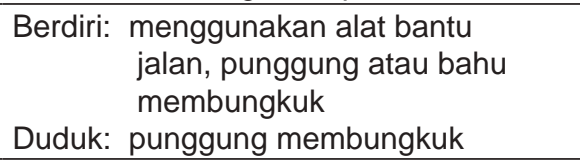 \\
\hline P4 & $\begin{array}{l}\text { Berdiri: } \\
\text { punggung membungkuk, kaki } \\
\text { terbuka lebar dan kepala } \\
\text { condong kedepan serta tidak } \\
\text { mampu berdiri terlalu lama dan } \\
\text { menggunakan satu kaki } \\
\text { Duduk: } \begin{array}{l}\text { punggung membungkuk, kepala } \\
\text { condong ke depan }\end{array} \\
\end{array}$ \\
\hline P5 & $\begin{array}{l}\text { Berdiri: } \\
\text { punggung membungkuk, kaki } \\
\text { terbuka lebar dan kepala } \\
\text { condong kedepan serta tidak } \\
\text { mampu berdiri menggunakan } \\
\text { satu kaki } \\
\text { Duduk: } \begin{array}{l}\text { punggung membungkuk, kepala } \\
\text { condong ke depan }\end{array} \\
\end{array}$ \\
\hline
\end{tabular}

Tabel 4 menunjukkan bahwa setelah melakukan latihan ROM selama 6 hari dengan frekuensi latihan satu kali dalam sehari pada partisipan 1 dan 2 ternyata tidak memberikan perubahan pada postur tubuh lansia. Partisipan 3, 4, dan 5 juga mengalami hal serupa setelah 4 kali latihan yaitu postur tubuh tidak mengalami perubahan atau sama dengan kondisi saat pertemuan pertama.

Postur tubuh mengacu pada posisi sendi dan otot yang dapat meningkatkan keseimbangan dan fungsi maksimal tubuh selama berdiri, duduk, dan berbaring. Kelainan postur dapat mengganggu kesejajaran dan mobilisasi dari tubuh (6). Pada tingkat perkembangan lansia terjadi penurunan pada postur tubuh berupa postur yang menekuk dan penurunan pada tulang belakang dada (kifosis). Tindakan yang dapat dilakukan pada perubahan postur tersebut yaitu olah raga teratur, pemeliharaan berat badan, kebutuhan nutrisi yang tinggi protein, kalsium dan vitamin D, serta berpindah (12). Lansia mengalami perubahan pada proses pembentukan tulang yang disebabkan peningkatan resorbsi tulang yang merupakan kerja dari osteoklas dan gangguan regulasi osteoblas yang berfungsi dalam pembentukan tulang baru. Hal tersebut menyebabkan pengapuran atau kepadatan tulang berkurang (4).
Berdasarkan hasil penelitian dan teori yang mendukung dapat disimpulkan bahwa latihan ROM tidak berpengaruh pada peningkatan postur tubuh. Hal tersebut disebabkan perubahan pada tulang akibat penuaan dan latihan ROM yang dilakukan juga tidak teratur dan tindakan hanya menggerakkan tubuh tanpa melakukan sebuah perpindahan serta untuk pemenuhan kebutuhan nutrisi pada lansia sering tidak terpenuhi sebagai akibat dari penurunan fungsi dari berbagai sisitem tubuh. Kesimpulan ini dapat diperkuat oleh hasil penelitian yang mengatakan bahwa analisis parameter karakteristik kemiringan individu terdapat hasil yang bervariasi antara kelompok usia yang berbeda. Sudut tubuh terbukti mengalami peningkatan dengan usia. Kejadian kifosis toraks meningkat dengan usia. Peningkatan asimetris tersebut menunjukkan secara signifikan bahwa sudut kifosis toraks lebih tinggi dari garis bahu dan perbedaan ketinggian sudut bahu terendah pada pengukuran kelompok wanita yang lebih tua (13).

\section{Gerakan}

Berdasarkan hasil analisis data pada 5 partisipan, gerakan lansia terbagi menjadi 5 sub tema atau kategori yaitu: cara dan kemampuan berjalan, kemampuan motorik halus, kemampuan motorik kasar, gemetar dan kemampuan berpindah. Keenam komponen yang menjadi sub tema dari gerakan merupakan fungsi tubuh yang melibatkan 4 bagian dasar yang saling berhubungan. Perubahan pada cara dan kemampuan berjalan juga ditunjukkan oleh partisipan 1 dan 2 pada pertemuan keenam. Berikut pernyataan partisipan:

"ya berubah, tadinya kan kalau jalan dari sini ke poli aja udah sininya (memegang bahu) kayaknya udah bungkuk gitu ya sekarang udah ngga begitu. Kalau saya kira agak lebih cepetan dikit mba tapi cuman dikit soalnya ngga tiap hari ya dilatih sama mbae" (P1)

"yo lurus biasa, pake ini (menunjuk kruk)" (P2)

Hasil wawancara menununjukkan bahwa kamampuan motorik halus lansia terdiri dari kemampuan berpakaian atau menyisir rambut, dan melakukan kesenian atau ketrampilan. Hal tersebut berdasarkan pernyataan dari partisipan berikut:

“sendiri (berpakaian atau menyisir rambut)" (P1) 
"saya punya ketrampilan ini kerajinan yah, saya dari kecil memang hobi sama kerajinan tangan itu merajut, menyulam kristik itu saya bisa semua sambilin jahit mesin itu juga bisa. Ini teman-teman kalau ngejahit minta tolong saya." (P3)

"kalau gini terasa sakit to (memperagakan ketika membuka baju, tangan terasa sakit). lyah dikiri ini yang sakit, saya ginikan (memperagakan melepas baju) nanti lepas ginikan terasa sakit." (P4)

"anu kegiatan yang bisa menyenangkan hati, badan olah raga apa senam sama apa-apa ada kegiatan menyanyi-menyanyi, joget-joget, karawitan, satilan, joget satilan itu"(P5)

Setelah melakukan latihan 6 kali P1 menunjukkan bahwa masih mengalami gemetar saat menggerakkan tangan terlalu lama. Hal tersebut sesuai dengan pernyataan berikut:

"ngga gemetar" (P1, P2)

(tangan gemetar saat diangkat terlalu lama)

Berdasarkan data hasil penelitian pada masingmasing sub tema dari gerakan dapat disimpulkan bahwa latihan ROM memberikan perubahan pada kemampuan lansia dalam melakukan pergerakan. Perubahan yang dirasakan hanya sedikit dan berbeda-beda pada setiap lansia. Perubahan tersebut dapat terlihat pada cara dan kemampuan berjalan, kemampuan motorik halus, dan pengalaman gemetar. Pergerakan dan koordinasi tubuh dipengaruhi oleh sistem skeletal, otot dan saraf untuk menghasilkan pergerakan yang seimbang halus dan terarah (5). Gaya berjalan merupakan bagian dari pergerakan yang perlu dikaji untuk menentukan mobilitas seseorang (6). Gerakan dipengaruhi pertumbuhan dan perkembangan, kesehatan fisik dan mental, gaya hidup, kelemahan dan stress serta faktor lingkungan $(2,5)$.

Berdasarkan hasil penelitian dan teori yang mendukung dapat disimpulkan bahwa latihan ROM dapat memengaruhi perubahan gerakan pada lansia. Perubahan yang terjadi pada lansia tersebut berbeda-beda sebagai akibat dari faktor-faktor yang memengaruhi dari kondisi lansia itu sendiri. Hal tersebut dapat didukung oleh hasil penelitian yang mengatakan bahwa rentang gerak aktif untuk semua pengukuran meningkat diseluruh mingg, tidak ada perbedaan antara kelompok dengan pengecualian total ketinggian aktif yang lebih besar pada semua pengukuran diwaktu tertentu untuk kelompok yang dipercepat (14). Hasil penelitian tersebut dapat dikaitkan dengan hasil penelitian di BPSTW Unit Abiyso Yogyakarta ditunjukkan dengan semakin meningkatnya rentang gerak maka kemampuan melakukan pergerakan juga akan mengalami peningkatan.

\section{SIMPULAN DAN SARAN}

Berdasarkan hasil penelitian dan pembahasan serta uraian dari bab-bab sebelumnya maka dapat disimpulkan setelah latihan ROM 6 kali untuk partisipan 1, 2 dan 4 kali untuk partisipan 3, 4, 5 menunjukkan bahwa ada pengaruh sebagian dari latihan ROM terhadap mobilitas fisik lansia di BPSTW Unit Abiyoso Yogyakarta. Peningkatan rentang gerak terjadi pada bagian leher, siku, pergelangan tangan, tangan dan jari serta lutut. Serta berkurangnya kekakuan sendi. Kekuatan otot terdiri dari satu kategori yaitu derajat kekuatan otot. Kekuatan otot lansia di BPSTW Unit Abiyoso Yogyakarta tidak mengalami peningkatan. Latihan ROM dapat meningkatkan perasaan senang, nyeri berkurang. Latihan ROM tidak berpengaruh pada masalah sesak nafas dan kecemasan lansia. Latihan ROM memberikan sedikit perubahan pada cara dan kemampuan berjalan lansia tetapi tidak memberikan perubahan pada lansia dengan keluhan sesak nafas. Postur tubuh (berdiri, duduk) dan kekuatan otot tidak mengalami perubahan.

Berdasarkan hasil penelitian ini, maka peneliti memberikan rekomendasi kepada petugas kesehatan di BPSTW Unit Abiyoso Yogyakarta untuk membuat rencana program kegiatan latihan $\mathrm{ROM}$ agar dimasukkan ke dalam intervensi keperawatan bagi lansia yang mengalami masalah gangguan mobilitas fisik.

\section{RUJUKAN}

1. WHO. World Health Statistics 2014: Large Gains in Life Expectancy [Internet]. 2015 [cited 2015 Nov 23]. Available from: http://www.who.int/ mediacentre/news/releases/2014/world-healthstatistics-2014/en/

2. Badan Pusat Statistik. Statistik Penduduk Lanjut Usia 2014. Jakarta: Badan Pusat Statistik; 2015.

3. Dinas Kesehatan Daerah Istimewa Yogyakarta. Profil Kesehatan Daerah Istimewa Yogyakarta tahun 2013. Yogyakarta: Dinas Kesehatan DIY; 2013. 
4. Miller CA. Nursing For Wellness in Older Adults. 6th ed. Philadelphia: Wolters Kluwer Health; 2012.

5. Kozier B, Erb G. Buku Ajar Fundamental Keperawatan: Konsep, Proses dan Praktik. Jakarta: EGC; 2010.

6. Potter PA, Perry AG. Buku Ajar Fundamental Keperawatan: Konsep, Proses dan Praktik. 4th ed. Jakarta: EGC; 2005.

7. Stanley M, Beare PG. Buku Ajar Keperawatan Gerontik. Jakarta: EGC; 2006.

8. Battaglia G, Bellafiore M, Caramazza G, Paoli A, Bianco A, Palma A. Changes in spinal range of motion after a flexibility training program in elderly women. Clin Interv Aging [Internet]. 2014 Apr [cited 2015 Nov 29];653. Available from: https:// www.ncbi.nlm.nih.gov/pmc/articles/PMC3990364/ pdf/cia-9-653.pdf.

9. Moleong LJ. Metodologi Penelitian Kualitatif. Bandung: PT Remaja Rosdakarya; 2012.

10. Smeltzer, Bare. Buku Ajar Keperawatan Medikal Bedah Brunner \& Suddarth. 12th ed. Jakarta: EGC; 2010.
11. Shin DS, Song R, Shin EK, Seo SJ, Park JE, Han SY, et al. [Effects of passive upper arm exercise on range of motion, muscle strength, and muscle spasticity in hemiplegic patients with cerebral vascular disease]. J Korean Acad Nurs [Internet]. 2012 Dec [cited 2016 Jun 22];42(6):783-90. Available from: http://www. ncbi.nlm.nih.gov/pubmed/23364033.

12. Taylor CR, Lillis C, Lemone P, Lynn P. Fundamental of Nursing: The Art and Science of Nursing care. 7th ed. China: Wolters Kluwer Health; 2011.

13. Drzał-Grabiec J, Snela S, Rykała J, Podgórska J, Banaś $A$. Changes in the body posture of women occurring with age. BMC Geriatr [Internet]. 2013 Oct 12 [cited 2016 Jun 13];13:108. Available from: http://www.ncbi.nlm.nih.gov/pubmed/24119004.

14. Düzgün I, Baltacı $G$, Turgut $E$, Atay $O A$. Effects of slow and accelerated rehabilitation protocols on range of motion after arthroscopic rotator cuff repair. Acta Orthop Traumatol Turc [Internet]. 2014 [cited 2016 Jun 13];48(6):642-8. Available from: http://www.ncbi.nlm.nih.gov/pubmed/25637728. 